\title{
THE CORRELATION BETWEEN STUDENTS' GRAMMAR MASTERY AND THEIR PERFORMANCE IN WRITING DESCRIPTIVE TEXT AT THE TENTH CLASS OF SMK MUHAMMADIYAH 1 METRO ACADEMIC YEAR 2012/2013
}

\author{
By Een Fariyanti \& Eva Faliyanti \\ Teacher Training and Education Faculty, Muhammadiyah University of Metro, Metro Indonesia 3411
}

\begin{abstract}
Writing is a language skill that is used for indirect communication to convey a message or information to the readers. In writing a text, we can explore our ideas, feelings and thoughts which are arranged in words, sentences, and paragraph by using eyes, brain and hand. In writing a text, we must be able to use a good language and we also must be able to arrange good sentences grammatically in order the readers understand about the content of our writing. Besides that, if the students will make a sentences or paragraph, they must have knowledge about tenses. The objectives of the research are to find out the students' simple grammar mastery and their performance in writing descriptive and also to find out whether or not there is a correlation between the students' grammar mastery and their performance in writing descriptive. The subjects of this research are the tenth grade of SMK Muhammadiyah 1 Metro (class XA1 and class XAP). In this research, the writer used descriptive quantitative method because the final score of variable is number and the analysis is using statistic. The researcher tried to analyze the current data about students' grammar mastery and their performance in writing descriptive. In collecting data, the researcher administered two kinds of test. They are simple present tense test and writing test. The simple present tense test are consists of 20 items of multiple choice and the writing test, the students choose one of topics from three topics. The result of this research shows that the students' simple present tense mastery was middle. It can be seen from the average of simple present tense test is 70.6. The students' performance in writing descriptive was middle. It can be seen from the average of writing descriptive test is 74.9. The conclusion above was from result of data analysis, it was found that writing descriptive affected by simple present tense mastery.
\end{abstract}

Key Words : Writing Descriptive Performance, The students' Grammar Mastery.

English skills have four skills, listening, speaking, reading and writing. In Indonesia, it is the first foreign language that must be taught as the compulsory subject starting from elementary school, junior high school, senior high school, up to university other higher education institution, it is hoped the student are able to speak, read and write English well, it can be seen that when the students are asked to answer the question by using
English and also difficult to give ideas or opinion. Even though, the object of teaching and learning English is to enable the student to use English as a communication it means that the students are able to use the language in communication.

Structure is very important to know, because it is one of the components of English material. The students will have 
difficulty in understanding language without knowing it well. A structure consists of rules which explain the particularities of the problem. So teacher should be careful in teaching tense.

Writing is a language skill that is used for indirect communication to convey a message or information to the readers. In writing a text, we can explore our ideas, feelings and thoughts which are arranged in words, sentences, and paragraph by using eyes, brain and hand. In writing a text, we must be able to use a good language and we also must be able to arrange good sentences grammatically in order the readers understand about the content of our writing. Thus, writing is basically the process of expressing ideas thoughts by using knowledge of structure and vocabulary to combine our ideas as a means communication. To express our mind in writing, it is not easy to make the readers understand about our writing. Many people who can speak well but they have difficulty to express their idea in writing. If they only can write their idea well, usually it happens after they practice to write intensively, such as at school, and college to learn their experience, because writing performance is a product of learning process and practice. In fact, some of students get difficulties in writing. The most of students have problems in mastering grammar which can be complicated. To make a sentence in English we need an understanding about English tenses. There are 12 tenses and in this case simple past tense in used. It is a part of English grammar that important and it always connects with other grammar. English and Indonesia have different structure. So, the students must study about it seriously. Simple present tense is basic of them. Besides that, when the students will make a sentences or paragraph, they must have knowledge about tenses, the formula especially. But actually, the students often forget about formula. They only remember it when it is studying, but in other time they will forget it. So, the formulas are not only remembered but understood too. The difficultness students' in writing sometime make they forget to put of punctuation and translate their sentences in English. So, the students should have a good knowledge about tenses, in this case simple present tense especially. Writing performance can express our idea that heard, read and see in writing form. Writing performance be able to enrich vocabularies. The purpose of this research is to give information that writing performance affected by simple present tense. Simple present tense can help in writing performance.

\section{METHODOLOGY}

In this research, the writer used correlation study (product moment) that is one of quantitative descriptive design. So, Correlation study here means that the writer uses one group and takes the data in one time without giving any treatment. In doing this research, the researcher used test to get the data of student's grammar mastery and their performance in writing descriptive.

Before the instrument was used, it had been tried out first. The main purpose of conducting it was to find out the validity, reliability, Normality items of present tense in a multiple choice test. The field of this research is the tenth class of SMK Muhammadiyah 1 Metro.

The data analyzed using quantitative data. It was used formula of the Pearson Product Moment correlation coefficient as follow:

$$
r_{X Y}=\frac{N(\Sigma X Y)-(\Sigma X)(\Sigma Y)}{\sqrt{\left\{N \Sigma X^{2}-(\Sigma X)^{2}\right\}\left\{N \Sigma Y^{2}-(\Sigma Y)^{2}\right\}}}
$$


Explanation:

$N=$ The number of the students in the sample

$r_{X Y}=$ The coefficient validity between $\mathrm{X}$ and $\mathrm{Y}$

$X=$ The number of $\mathrm{x}$ score (simple present tense)

$\mathrm{Y}=$ The number of $\mathrm{y}$ score (writing descriptive performance)

$X^{2}=$ The number of squares of $\mathrm{x}$

$\mathrm{Y}^{2}=$ The number of squares of $\mathrm{y}$ scores

$X Y=$ The total of $\mathrm{X}$ and $\mathrm{Y}$.

(Arikunto, $2006: 276$ )

Then from calculation result of interpreting the coefficient correlation according to Arikunto (2006:57) as follow:

\begin{tabular}{|c|c|c|c|}
\hline Aspect & $\mathrm{X} 1$ & $\mathrm{X} 2$ & $\mathrm{X} 3$ \\
\hline Rata-rata & 0.74 & 0.43 & 0.71 \\
\hline
\end{tabular}

Between : $0.800-1.00$ is very high correlation

Between : $0.600-0.800$ is high correlation

Between : $0.600-0.800$ is high correlation

Between : $0.400-0.600$ is enough correlation

Between : $0.200-0.400$ is low correlation

Between : $0.00-0.200$ is very low correlation

\section{FINDING}

The Data Analysis of Students' Simple Present Tense Mastery

Based on the test of simple past tense mastery, here the writer would like to show the result of the average of simple present tense mastery.

Formula:

$\bar{X}=\frac{\sum X}{N}$

$$
=\frac{3320}{47}=70.6
$$

From the result, the average of simple present tense mastery is 70.6.

In this research the writer use objective test of simple present tense test. That was multiple choice tests. The test consists of 20 item tests. The test consists three indicators, that are the students should be able to use simple present tense sentence in aspect of formula (X1), aspect adverb of time(X2), and aspect of verb (X3).

\section{The table of analysis indicators of simple past tense}

Based on the table it can be seen that:

1. The high indicator on aspect $\mathrm{X} 2$ with 0.74 .

2. The middle indicator on aspect $\mathrm{X} 1$ with 0.43 .

3. The low indicator on aspect $\mathrm{X} 3$ with 0.71 .

To find invariant frequency distribution of the students' simple present tense mastery, the writer would like to use the following formula:

$$
I=\frac{N T-N R-1}{k}
$$

(Nurkancana 1983:114). 
Explanation:

I : Interval

NT : The highest score

NR : The lowest score

$\mathrm{k} \quad$ : Criterion

From the table above, it can be seen that the highest and the lowest score of students' simple present tense mastery. The highest score is 90 and the lowest score is 40 .

So the interval:

$I=\frac{90-40-1}{3}$

$=16,333$ roundness 17

From the result of interval, the writer would like to find how many students, who get the high, fail and low as the following table:

Table of The invariance frequency distribution of simple past tense mastery

\begin{tabular}{|c|c|c|c|}
\hline Internal & $\begin{array}{c}\text { Categor } \\
\text { ies }\end{array}$ & $\begin{array}{c}\text { Freque } \\
\text { ncy }\end{array}$ & Perc (\%) \\
\hline $74-90$ & High & 26 & $55.3 \%$ \\
$57-73$ & Middle & 12 & $25.5 \%$ \\
$40-56$ & Low & 9 & $19.2 \%$ \\
\hline \multicolumn{2}{|r|}{ Total } & 47 & $100 \%$ \\
\hline
\end{tabular}

Source: The Data Analysis of invariant frequency distribution of students' simple present tense mastery

From the table above, the writer made classification as follows:

1. There are 26 students or $55.3 \%$ who get high score.

2. There are 12 students or $25.5 \%$ who get middle score.

3. There are 9 students or $19.2 \%$ who get low score.
The Data Analysis of Writing Descriptive Performance

Based on the test of writing descriptive performance, here the writer would like to show the result of the average of writing descriptive performance.

Formula:

$$
\begin{aligned}
\bar{X} & =\frac{\sum X}{N} \\
& =\frac{3520}{47}=74.9
\end{aligned}
$$

From the result, the average of paragraph writing performance is 74.9 .

To find invariant frequency distribution of writing descriptive performance, the writer would like to use the following formula:

$I=\frac{N T-N R-1}{k}$

(Nurkancana 1983:114).

Explanation:

I : Interval

NT : The highest score

NR : The lowest score

$\mathrm{k} \quad$ : Criterion

From the table above, it can be seen that the highest and the lowest score of students' paragraph writing performance. The highest score is 88 and the lowest score is 52 .

So the interval:

$$
\begin{aligned}
I & =\frac{80-50-1}{3} \\
& =11.666 \text { roundness } 12
\end{aligned}
$$

From the result of interval, the writer would like to find how many students, who get the high, fail and low as the following table: 
Table of The invariance frequency distribution of paragraph writing performance

\begin{tabular}{|c|c|c|c|}
\hline Internal & Categories & Frequency & Perc $(\%)$ \\
\hline $77-88$ & High & 18 & $38.3 \%$ \\
\hline $65-76$ & Middle & 20 & $42.6 \%$ \\
\hline $52-64$ & Low & 9 & $19.1 \%$ \\
\hline \multicolumn{2}{|c|}{ Total } & 47 & $100 \%$ \\
\hline
\end{tabular}

Source: The Data Analysis of invariant frequency distribution of writing descriptive performance

From the table above, the writer made classification as follow:

1. There are 18 students or $38.3 \%$ who get high score.

2. There are 20 students or $42.6 \%$ who get middle score.

3. There are 9 students or $19.1 \%$ who get low score.

The Data Analysis of Variant Frequency Distribution of Students' Simple Present Tense Mastery and Writing Descriptive Performance

To know how many students, who get high, fair and low whether in the simple present tense mastery and writing descriptive performance, the writer would like to analysis variant frequency distribution of the students' simple present tense mastery and writing descriptive performance. It is base on table. To be clear see the following table:

Table of The invariance frequency distribution of students' simple present tense mastery and writing descriptive performance

\begin{tabular}{|l|l|l|l|l|}
\hline $\begin{array}{c}\text { Simple } \\
\text { Present } \\
\text { Tense }\end{array}$ & \multicolumn{3}{|c|}{ Writing Descriptive } & Total \\
\cline { 2 - 4 } & High & $\begin{array}{c}\text { Middl } \\
\mathrm{e}\end{array}$ & Low & \\
\hline High & 14 & 12 & - & 26 \\
\hline Middle & 4 & 4 & 4 & 12 \\
\hline Low & - & 4 & 5 & 9 \\
\hline Total & 18 & 20 & 9 & 47 \\
\hline
\end{tabular}

Source: The data analysis of frequency distribution of students' simple present tense mastery and writing descriptive performance

From the table above, the writer made classification as follow:

1. There are 14 students who got high score in simple present tense and writing descriptive.

2. There are 12 students who got high score in simple present tense but got fair score writing descriptive.

3. There are 4 students who got fair score in simple present tense and high score in writing descriptive.

4. There are 4 students who got fair score in simple present tense and writing descriptive.

5. There are 4 students who got fair score in simple present tense but got low score in writing descriptive.

6. There are 4 students who got low score in simple present tense and fair score in writing descriptive.

7. There are 5 students who got low score in simple present tense and writing descriptive.

From the description above, it can be seen that:

1. The students' writing descriptive will be high and fair if the students' simple present tense will be high and fair.

2. The students' writing descriptive will be high, fair and low if the students' simple present tenses are high, fair and low.

3. The students' writing descriptive will be fair and low if the students' simple present tense will be fair and low. 


\section{CONCLUSION AND SUGGESTION}

Based on the objective of the research and the result of the analysis, the writer concludes the result that the first conclusion was the average of simple present tense mastery test is 70.6 , with middle criteria. It means that the students quite master simple present tense in three aspects; there are formula, adverb of time and verb. It was proved by the highest score of simple present tense test was 90 and no one of students got score under 40. The second conclusion that the average of writing descriptive performance test is 74.9 , with middle criteria. It means that the students quite master in writing descriptive performance in expressing the idea, read and see in writing form and enrich vocabularies. It was proved by the highest score of paragraph writing performance test is 88 and no one of students got score under 52 .

The conclusion above was from result of data analysis, it was found that writing descriptive performance affected by simple present tense mastery.

Based on the result and conclusion of the research stated previously, the writer proposes some suggestions for the teacher and student. To make the students have good performance in writing descriptive, it would be better for teacher to give their students much knowledge about simple present tense. Teacher must apply many techniques to improve the students' simple present tense mastery. In order to have good writing performance, the students have to master simple present tense. The students should improve their simple present tense because it is an important element in writing. The students should have motivation to study again and they must be active in the class.

\section{REFERENCE}

Arikunto, Suharsimi. (2006). Prosedur Penelitian Suatu Pendekatan Praktik. Jakarta. Bumi Aksara

Arikunto, Suharsimi (2010). Prosedur Penelitian, Suatu Pendekatan Praktik, Edition Revision VII. Jakarta. PT. Rineka Cipta.

Easwood, John (1994). Oxford Guide to English Grammar. England Oxford University Press.

Robert et al. (2010). Grammar 1. Kediri. Mahesa Institute press.

Oxford University (2003). Definision of Mastery. Oxford University Press. Online Dictionary. Accesed from http://oxforddictionaries.com/defin ition/english/mastery

Sugiyono (2010). Metode Penelitian Pendidikan Pendekatan Kuantitatif, kualitatif, dan $R \& D$. Bandung: Alfabeta.

Brown, Kristine and Hood, Susan ( 1993). Writing Matter. Cambridge University Press

Turmudi, Dedi (2012). Smart and skillful writer: developing writing 2. Metro. UM Metro.

WordNet (2012). Definision of Mastery. Princeton University, Farlex Inc.online dictionary. Accesed from

http://www.thefreedictionary.com/ mastery

Indra Susilo. (2006). Correlation Between Grammar Mastery and Students, Guided Writing Ability at the Second Semester of Eleventh 
Class of SMA Persada Bandar

Lampung. Published Lampung

University. Lampung

Sri Lestari. (2007). Increasing The

Students' Writing Simple

Sentence in Simple Present Tense

Mastery Through Picture at The

First Year of SMP N 2

Purbolinggo East Lampung.

Published Muhammadiyah

University of Metro. Lampung

Tim Dosen Universitas Muhammadiyah. (2012). Guidance for Proposal-

Seminar S-I Thesis.Penerbit Universitas Muhamadiyah Metro.

Lampung 